\title{
Effect of Vegetation Structure and Species Composition on above Ground Biomass and Carbon in Forests of Central Western Ghats, India
}

\author{
T.S. Hareesh* and C. Nagarajaiah \\ Department of Forestry and Environmental Sciences, College of Agriculture, UAS, GKVK, \\ Bengaluru 560 065, India \\ *Corresponding author
}

\section{A B S T R A C T}

Keywords

Western Ghats, Diversity, Above Ground biomass, Carbon, Kodagu

Article Info

Accepted:

20 March 2019

Available Online:

10 April 2019
The present study was carried out to quantify the changes in tree diversity and aboveground biomass in three different forest types existed in the Kodagu district of Central Western Ghats. Data on species richness, diversity, composition, above ground biomass (AGB) of trees, shrub and herbs, carbon stock were collected from 120 sample plots of 400 $\mathrm{m}^{2}$. Results revealed that evergreen forests recorded higher richness (141 species), diversity, density, basal area, biomass and carbon than other two forest types of the district. AGB from three forest types ranged from 175 to $233 \mathrm{Mg} \mathrm{ha}^{-1}$. Our study shows that not only density that governs the AGB, however basal area, an important factor contributing to AGB and carbon stock. Trees in higher girth classes particularly, $>180 \mathrm{~cm}$ gbh, contained higher amount of biomass carbon and removal of such trees will have considerable impact on carbon dynamics of the region.

\section{Introduction}

Natural forests are very important landscapes known for the diverse assemblage of species in their ecosystem and form a very productive ecosystem. These forests act as store house for approximately $40 \%$ terrestrial carbon. Even one third of the net primary productivity is attributed from these forests. Storage of carbon in the dominant tree component and computing the carbon cycling at regional as well as global level is done through the studies on forest biomass. Measurement of above ground carbon (AGB) of dominant species in different forest communities or plant functional types is of great importance because dominant trees species greatly influence the magnitude and pattern of energy flow that is stored in trees in the form of various substances which are in continues circulation between biotic and abiotic components of ecosystem (Behera et al., 2016). Estimating AGB is a useful measure for comparing structural and functional attributes of forest ecosystems across a wide range of environmental conditions (Brown et al., 1999).

Western Ghats forests are unique in terms of its endemism with more than 350-400 trees 
and liana species are co-existed together (Murthy et al., 2016). In these forests, species are represented by different diameter classes and act as a potential carbon sink with sequestration potential of $80-150 \mathrm{Mg} \mathrm{C} \mathrm{ha}{ }^{-1}$ (Devagiri et al., 2013). These unique landscapes are experiencing a serious threat of degradation due to habitat destruction and fragmentation. Change in land-use practices is the major cause for loss of biodiversity in this area. Land-use change will be responsible for pushing many species to various kinds of threats and alter the ecosystem function and provision of ecosystem services (Phillips et al., 2017). Impact of tropical forest disturbance on biodiversity was more severe in Asia than in Africa, South America and Central America (Gibson et al., 2011). The change in land-use types and degradation of forests will alter the carbon cycle. Approximately $35 \%$ of the anthropogenic $\mathrm{CO}_{2}$ emission resulted directly from land-use changes (Turner et al., 2007; Carlson et al., 2013). Understanding of pattern of tree diversity, vegetation structure and its contribution to above ground biomass (AGB) carbon among the various forest types can help in planning conservation and climate mitigation strategies. Studying the AGB patterns in different ecosystems or in plant functional types will help to understand the response of climatic changes on these forest types and future scenarios. Species level AGB measurements in different forest types will help in identifying the keystone species sequestering higher AGB for sustainable carbon stock management and biodiversity conservation and also help to validate the projections of global carbon model output with ground data (Behera et al., 2017).

Most of the earlier studies aimed to quantify the floristic diversity, biomass carbon and its dynamics. Very little work had been reported on impact on diversity, girth class, basal area towards AGB and carbon in different forests.
Hence a study was undertaken in Kodagu district of Karnataka to understand species diversity, congregation in particular girth class and basal area and in turn their effect on above ground biomass and carbon across different types of forest exist in Kodagu district.

\section{Materials and Methods}

\section{Study site}

The study was conducted in different forest types of Kodagu district in the Central Western Ghats region $\left(70^{\circ} 25^{\prime}-76^{\circ} 14^{\prime} \mathrm{E}\right.$ and $\left.12^{\circ} 15^{\prime}-12^{\circ} 45^{\prime} \mathrm{N}\right)$. Kodagu covers an area of $4106 \mathrm{~km}^{2}$, out of which nearly $43 \%$ of the total area is under natural forest cover. Evergreen and moist deciduous forests are the major types existed towards the westward side and south part, followed by smaller area under dry deciduous forest type which is occupied towards the eastern side of the district. The evergreen and moist deciduous forest types have altogether different species composition. The district experience climatic gradient for temperature and rainfall from west to eastward side. Elevation in the study area ranges from 300 to $1300 \mathrm{~m}$ above sea level (a.s.l) with a rainfall from 1500 to 3500 $\mathrm{mm}$ in a year. The $90 \%$ of the rainfall receives in June to September month and occasional rains during summer. Temperature ranges from $15^{\circ} \mathrm{C}$ to $32^{\circ} \mathrm{C}$ with mainly lateritic to red loamy soil.

\section{Data collection and sampling design}

Evergreen forest (EGF), moist deciduous forest (MDF) and dry deciduous forest (DDF) types were considered for the study. Sampling locations across the various forest types were shown in the Figure 1. The evergreen and moist deciduous forests were selectively logged until the 1980s, after the enacting the Forest Conservation Act, 1980 the 
commercial harvest of species were banned in these forests (Kushalappa and Kushalappa, 1998). However, these forests were undergoing small scale biotic interferences such as grazing, the collection of fuelwood, illegal harvesting, fire etc., by the local people. During the colonel period, some parts of forests were clear felled and artificially planted with Teak and mixed tree species, later in the mid of the $19^{\text {th }}$ century, the privately owned forests in this region were converted to coffee plantations by retaining many of the original native trees existed over there as shade cover to coffee, hence $33 \%$ of the total area of the district is under shadegrown coffee, which mimic forested landscape.

A nested sampling approach was adopted for the collection of data on trees (nondestructive approach), shrubs and herbs (destructive approach; Fig. 2). Forty quadrats of $20 \mathrm{~m} \times 20 \mathrm{~m}$ size were laid randomly in each forest types, within these plots all the woody plants were identified at species level using field keys of Pascal and Ramesh (1987). Height and girth at breast height (GBH) of the trees above $30 \mathrm{~cm}$ were measured using Blume Leiss Hypsometer and measuring tape respectively. The unidentified specimens were later got identified at College of Forestry, Ponnampet with the help of taxonomist. Within the quadrat, two $5 \times 5 \mathrm{~m}$ nested quadrats will be laid at opposite corners to collect data on the shrubs and five $1 \mathrm{x} 1 \mathrm{~m}$ nested quadrats were laid at four corners and one at the middle of the quadrats for recording the data on herbs (Fig. 2).

\section{Data analysis}

From the collected data, species richness (SR) was estimated by counting individuals of different tree species per unit area and plotting species-area accumulation curves as suggested by Chazdon et al., (2009). Species diversity (Shannon-Wiener Diversity Index$H^{\prime}$ ) and Simpson's index of dominance (D) was calculated as per Magurran (1988). Vegetation structure was characterized by using GBH classes, Importance Value Index (IVI) (sum of relative density, relative frequency and relative dominance) for each species among plots was computed (Curtis and McIntosh, 1950). Based in IVI values, top ten tree species were considered for calculation of density (stems ha ${ }^{-1}$ ) and basal area $\left(\mathrm{m}^{2} \mathrm{ha}^{-1}\right)$ and their contribution to AGB $\left(\mathrm{Mg} \mathrm{ha}^{-1}\right)$ and Carbon $\left(\mathrm{Mg} \mathrm{ha}^{-1}\right)$.

\section{Estimation of above ground biomass (AGB)}

For estimating the AGB, the strata considered was trees, shrubs and herbs. Tree biomass was estimated indirectly by non-destructive method by calculating the stem volume and wood density (Chave et al., 2005; Vashum and Jayakumar, 2012; Devagiri et al., 2013 and 2019). While biomass for shrubs and herbs was estimated using a destructive method. The data collected on tree parameters such as GBH and height were used for volume estimations using volume equations published by Forest Survey of India (FSI, 2006). For those species-specific volume, equations are not available, the regional volume equation, $\mathrm{V}=0.16948-$ $10.63682 \mathrm{D}^{2} \mathrm{H}$ was used for estimating the volume (FSI, 2006). Tree biomass was estimated by multiplying volume with wood density values of particular species obtained by Forest Research Institute (FRI, 1996). All shrubs and herbs occurring in sample plot of $5 \mathrm{~m} \times 5 \mathrm{~m}$ and $1 \mathrm{~m} \times 1 \mathrm{~m}$ respectively were harvested and oven-dried to estimate the weight. Biomass estimated for different strata were summed to calculate total AGB and expressed in $\mathrm{Mg}$ dry wt. ha ${ }^{-1}$. Carbon stock was estimated by multiplying estimated dry biomass weight with 0.47 as suggested by IPCC (2007). 


\section{Software's used}

The primary data consist of field observations, size class distribution of species, IVI, biomass, carbon estimations were done in MS-EXCEL 2013. Species diversity indices, richness, Jaccard's index of similarity were computed using BioDiversity Pro 2.0 software.

\section{Results and Discussion}

\section{Species density, diversity and $\beta$-diversity}

The number of stems (density) and diversity of species varied across the different forest types. Table 1 shows the species richness, diversity, tree density, basal area and similarity index present across three forest types. The number of species of 36,42 and 141 were recorded in dry deciduous, moist deciduous and evergreen forest, respectively. Shannon-Weiner diversity index $\left(H^{\prime}\right)$ of 4.55 was observed in evergreen forest type, whereas moist deciduous (2.99) and dry deciduous forest types (2.85) has a moderate diversity values. Simpson's index of dominance (D) indicates the probability of two species are the same when they are they are together randomly drawn from a population. Since evergreen forests are high in diversity, these forests possess a Simpson's index of 0.015 , followed by moist deciduous forest (0.084) and dry deciduous forest type (0.086). Similarity among the forests with respect to species turnover was expressed in terms of Jaccard's similarity index. It has been observed that $66.56 \%$ similarity exists between moist and dry deciduous forest types, these forests possess almost similar in number of species encountered, (moist deciduous forest is represented by 42 species; dry deciduous forest by 36 species) and have $66.56 \%$ of the species enumerated occurred both in moist and dry deciduous forests. There is $18.27 \%$ similarity among species composition between moist deciduous and evergreen forest types of the district. Similarly, dry deciduous and evergreen forest types have $15.67 \%$ similarity in terms of species composition.

\section{Vegetation structure}

Vegetation structure of all the forests is depicted in Figure 3. None of the forest types of Kodagu showed Reverse-J-shaped girth distribution. In all the forest types, the number of stems in the $30-60 \mathrm{~cm}$ GBH class is less when compared to the next GBH class. In deciduous forests, more number of stems $\mathrm{ha}^{-1}$ were found in 60-90 and 90-120 cm GBH class but lesser in lower girth class indicates abnormal growing stock. Whereas, in moist deciduous forest, more number of stems are present in 60-90 cm girth class. Comparatively evergreen forests had a good represent of trees in all the girth class and showed reverse-J shaped pattern which is commonly observed in climax forests of the Western Ghats forests.

\section{Species composition and assemblages}

Species composition varied across the different forest types and top ten species listed based on IVI among the three forest types are presented in Table 2. It has been observed that dry deciduous and moist deciduous forest types were differed by only four species (viz., Tectona grandis, Grewia teliea folia, Gmelina arborea and Cassia siamea) and eight species were commonly found in these two forest types were Anogeissus latifolia, Dalbergia latifolia, Lagerstroemia lanceolate, Lannea coromandalica, Pterocarpus marsupium, Terminalia bellarica, Terminalia paniculata and Terminalia tomentosa. In dry deciduous forest, Terminalia tomentosa was the dominant species (43.80) followed by Anogeissus latifolia (35.49), Lagerstromia lanceolate (35.28), Terminalia bellarica 
(30.24), Pterocarpus marsupium (23.50) etc. Moist deciduous forest was also dominated by Terminalia tomentosa, Lagerstromia lanceolate, Anogeissus latifolia, Dalbergia latifolia, Terminalia paniculata etc. In moist deciduous forest, Terminalia tomentosa and Lagerstroemia lanceolate were occupied by $53.30 \%$ and $29.96 \%$ among all the species followed by Anogeissus latifolia, Dalbergia latifolia and Terminalia paniculata. Evergreen forests have altogether different species composition, which was dominated by Eleocarpus tuberculatus, Olea diocca, Canarium strictum, Dimocarpus longan, Syzygium cumini etc. Eleocarpus tuberculatus was represented by $16.40 \%$ of all the tree species found in evergreen forests. Lagerstroemia lanceolate was the only species found common among the evergreen, moist deciduous and dry deciduous forest types.

\section{Above-ground biomass and carbon stock}

Above ground biomass (AGB), carbon (C) and carbon dioxide equivalent $\left(\mathrm{CO}_{2} \mathrm{e}\right)$ of different forest types from field measurements ranged are presented in Table 3. Across the various forest types, the AGB ranged from 175.14 $\mathrm{Mg} \mathrm{ha}^{-1}$ in the dry deciduous forest to 233.40 $\mathrm{Mg} \mathrm{ha}^{-1}$ in evergreen forest, whereas the moist deciduous forests possess an AGB of $190.57 \mathrm{Mg} \mathrm{ha}^{-1}$. The carbon content was higher in evergreen forests (109.70 $\left.\mathrm{Mg} \mathrm{ha}^{-1}\right)$, followed by moist deciduous (89.59 $\mathrm{Mg} \mathrm{ha}^{-1}$ ) and dry deciduous forests $\left(82.31 \mathrm{Mg} \mathrm{ha}^{-1}\right)$.

The contribution of different girth class on biomass $\left(\mathrm{Mg} \mathrm{ha}{ }^{-1}\right)$ by deciduous, moist deciduous and evergreen forest types are shown in Figure 4, 5 and 6, respectively. In the dry deciduous forest type, higher biomass was contributed by $90-120 \mathrm{~cm}$ girth class and their density is also more, whereas, in moist deciduous forests higher biomass was contributed by trees of $120-150 \mathrm{~cm}$ girth class, but their numbers are less. Similarly, in evergreen and dry deciduous forests, higher biomass stock was contributed by big trees of $>150 \mathrm{~cm}$ girth class however, density of individuals was less. In dry deciduous and evergreen forests, even though the density of trees in the girth class $60-90 \mathrm{~cm}$ was higher, but their contribution to biomass was found to be less.

\section{Species composition and their contribution to AGB}

In dry deciduous forest, Terminalia tomentosa

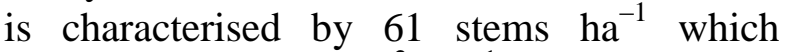
accounted for $6.32 \mathrm{~m}^{2} \mathrm{ha}^{-1}$ basal area and contributed $41.31 \mathrm{Mg} \mathrm{ha}^{-1}$ to total AGB (Table 4). Anogeissus latifolia was the second most dominated tree species (54 stems ha ${ }^{-1}$ with $4.07 \mathrm{~m}^{2} \mathrm{ha}^{-1}$ basal area) which contribute 14.97 $\mathrm{Mg} \mathrm{ha}^{-1}$ to total AGB. Compared to Anogeissus latifolia, Terminalia bellarica (19.33 $\mathrm{Mg} \mathrm{ha}{ }^{-1}$ ), Pterocarpus marsupium (16.84 $\mathrm{Mg} \mathrm{ha}^{-1}$ ), Lagerstroemia lanceolate (16.06 $\mathrm{Mg} \mathrm{ha}^{-1}$ ) have contribute more interms of above ground biomass, even though they have represented with a lesser number of trees. In moist deciduous forest, Terminalia

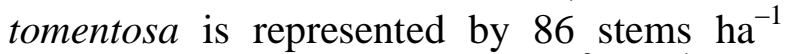
with a basal area of $8.61 \mathrm{~m}^{2} \mathrm{ha}^{-1}$ and contribute $56.64 \mathrm{Mg} \mathrm{ha}^{-1}$ to AGB. Second dominant species which contribute more biomass was Lagerstroemia lanceolate with 16.45 $\mathrm{Mg} \mathrm{ha}^{-1}$. Dalbergia latifolia $(10.59 \mathrm{Mg}$ $\mathrm{ha}^{-1}$ ) ranked $3^{\text {rd }}$ position in terms of biomass contribution, followed by Pterocarpus marsupium (9.27 $\mathrm{Mg} \mathrm{ha}^{-1}$ ), these two species were represented by a lesser number of individuals when compared to Anogeissus latifolia $\left(8.40 \mathrm{Mg} \mathrm{ha}^{-1}\right)$. In evergreen forest, the highest number of individuals were found in Elaeocarpus tuberculatus (27 stems $\mathrm{ha}^{-1}$ ), but their contribution to AGB is $10.44 \mathrm{Mg}$ $\mathrm{ha}^{-1}$, Artocarpus hirsutus contribute highest AGB (10.97 $\mathrm{Mg} \mathrm{ha}^{-1}$ ) among all, even though they have lesser number of individuals (8.75 
stem $\mathrm{ha}^{-1}$ ) when compared to Olea diocca (15.63 stem ha $\left.{ }^{-1}\right)$, Dimocarpus longan (15.63 stem $\left.\mathrm{ha}^{-1}\right)$, Litsea floribunda (13.75 stem $\mathrm{ha}^{-1}$ ) and Syzygium cumini (13.13 stem ha $\left.{ }^{-1}\right)$ which contribute less to AGB.

\section{Diversity, structure and composition}

Our study revealed that evergreen forests are highly diverse when compared to moist and dry deciduous forests. Higher diversity is attributed because these forests are less degraded when compared to the other two types, where trees of high commercially exploitable species occur. Evergreen forests receive highest degree of protection and they exist in inaccessible area, where human habitation is less, as a result, lesser biotic pressure (grazing, illegal felling, collection of non-timber forest produce etc.) on these forests when compared to moist and dry deciduous forests types. Many workers such as Murthy et al., (2016) reported less disturbed areas of Western Ghats are highly diverse than more disturbed areas. Pascal and Pelissier (1996) had reported a Shannon index of 3.6 to 4.3 at different altitudes of the Western Ghats. Swamy et al., (2010) mentioned a Shannon index of 2.0 to 3.7 and Simpson's index of 0.1 from different sites of evergreen forests of Kodagu region. For the evergreen forests of Kodagu region, Devagiri et al., (2019) reported a Shannon index of 2.90 and Simpson's index of 0.08 for the moist deciduous forests of Kodagu district.

Stem density per hectare (> $30 \mathrm{~cm} \mathrm{GBH})$ in the forests of Kodagu varies from 386 to 491, which was categorised as low in dry and moist deciduous forests to intermediate in evergreen forests according to Suratman (2012). Since commercial important timbers were exists in dry and moist deciduous forests and were highly exploited during earlier days, hence these forests possess lesser density. Swamy et al., (2010) reported a tree stand density ranges from 263 to 438 individual's $\mathrm{ha}^{-1}$ from evergreen forests of Kodagu. Devagiri et al, (2013) reported tree density of 1142 stems ha ${ }^{-1}$ with a basal area of $14.55 \mathrm{~m}^{2}$ $\mathrm{ha}^{-1}$ from the evergreen forest of Kodagu. A stem density of 314 trees $\mathrm{ha}^{-1}$ with a basal area of $18.91 \mathrm{~m}^{2} \mathrm{ha}^{-1}$ had been reported from the moist deciduous forests of Kodagu (Devagiri et al., 2019). Salunkhe et al., (2016) have reported a tree density between 14.8 and $59.3 \mathrm{ha}^{-1}$ and a basal area between 0.15 to $8.37 \mathrm{~m}^{2} \mathrm{ha}^{-1}$ from the dry deciduous forests of Madhya Pradesh. None of the forests of Kodagu showed exact reverse $\mathrm{J}$ shaped size class distribution, (with little exception for evergreen forests) and it have been observed that a lesser number of individuals in lower girth class (30-60 cm girth class). In dry deciduous forest, there was very less number of individuals in 30-60 $\mathrm{cm}$ and $60-90 \mathrm{~cm}$ diameter class. This pattern indicates that these forests experiencing regeneration problem where species are failing to grow normally due to the biotic pressure on the growth of the species, which hinders the passing of species from lower girth class to higher class. Murthy et al., (2016) reported a similar type of stand structure in Western Ghats of Karnataka due to disturbances.

\section{Variation in above ground biomass (AGB) and carbon stock}

Above ground biomass (AGB) varied between different forest types across the Kodagu, evergreen forest reported a biomass of $233 \mathrm{Mg} \mathrm{ha}^{-1}$ which was lower than what has been reported by Devagiri et al., (2019) for the evergreen forests of Kodagu. The moist deciduous and dry deciduous forests reported a biomass of $190.57 \mathrm{Mg} \mathrm{ha}^{-1}$ and 175.14 $\mathrm{Mg} \mathrm{ha}^{-1}$ respectively, whereas Pande (2005) reported the disturbed tropical dry deciduous teak forests of Satpura plateau, Madhya Pradesh possesses biomass ranged from $28.1-85.3 \mathrm{t} \mathrm{ha}^{-1}$ and Salunkhe et al., 
(2016) reported a biomass of $54.9 \mathrm{tha}^{-1}$ from dry deciduous forests of Madhya Pradesh. Higher biomass and carbon in an evergreen forest was attributed due to variation in stand density and a basal area which are crucial in determining the biomass production of the forest (Chave et al., 2003).

Table.1 Vegetation structure, diversity and species composition of different forest types of central Western Ghats

\begin{tabular}{|c|c|c|c|}
\hline \multirow[t]{2}{*}{ Parameters } & \multicolumn{3}{|c|}{ Forest Types } \\
\hline & Dry Deciduous & Moist Deciduous & Evergreen \\
\hline No. of species & 36 & 42 & 141 \\
\hline Shannon-Weiner Diversity Index $\left(H^{\prime}\right)$ & 2.85 & 2.99 & 4.55 \\
\hline Simpson's Index of Dominance (D) & 0.086 & 0.084 & 0.015 \\
\hline Tree Density (stems ha' ${ }^{-1}$ ) & 386.25 & 391.25 & 491.25 \\
\hline Basal Area $\left(\mathbf{m}^{2} \mathbf{h a}^{-1}\right)$ & 38.29 & 38.58 & 46.65 \\
\hline \multicolumn{4}{|l|}{ Jaccard's Similarity Index } \\
\hline Dry Deciduous & - & 66.56 & 15.67 \\
\hline Moist Deciduous & - & - & 18.27 \\
\hline Evergreen Forest & - & - & - \\
\hline
\end{tabular}

Table.2 Contribution of top ten tree species (based on IVI) to density, basal area, biomass and carbon across different forest types

\begin{tabular}{|l|c|c|c|}
\hline Species & Dry Deciduous & Moist Deciduous & Evergreen \\
\hline Anogeissus latifolia & $35.49(2)$ & $19.12(3)$ & - \\
\hline Artocarpus hirsutus & - & - & $7.87(3)$ \\
\hline Canarium strictum & - & - & $5.91(9)$ \\
\hline Cassia siamea & $08.01(9)$ & - & - \\
\hline Dalbergia latifolia & $22.02(6)$ & $16.23(4)$ & - \\
\hline Dimocarpus longan & - & - & $7.81(4)$ \\
\hline Elaeocarpus tuberculatus & - & - & $16.40(1)$ \\
\hline Gmelina arborea & $08.90(7)$ & - & - \\
\hline Grewia telieafolia & - & $12.70(9)$ & - \\
\hline Lagerstroemia lanceolate & $35.28(3)$ & $29.96(2)$ & $7.00(7)$ \\
\hline Lannea coromandalica & $07.57(10)$ & $13.22(8)$ & - \\
\hline Litsea floribunda & - & - & $7.13(6)$ \\
\hline Lophopetalum wightianum & - & - & $6.33(8)$ \\
\hline Mangifera indica & - & - & $5.54(10)$ \\
\hline Olea diocca & - & - & $8.06(2)$ \\
\hline Pterocarpus marsupium & $23.50(5)$ & $14.79(6)$ & - \\
\hline Syzygium cumini & - & - & $7.58(5)$ \\
\hline Tectona grandis & - & $14.13(7)$ & - \\
\hline Terminalia bellarica & $30.24(4)$ & $11.20(10)$ & - \\
\hline Terminalia paniculata & $08.25(8)$ & $16.19(5)$ & - \\
\hline Terminalia tomentosa & $43.80(1)$ & $55.30(1)$ & - \\
\hline
\end{tabular}

Values in bracket indicates the ranking based on IVI in their forest types 
Table.3 Above ground biomass (AGB) and carbon in different forest types (Mean \pm SE)

\begin{tabular}{|c|c|c|c|c|c|c|}
\hline \multirow[t]{2}{*}{ Forest types } & \multicolumn{4}{|c|}{ Above ground live biomass $\left(\mathrm{Mg} \mathrm{ha}^{-1}\right)$} & \multirow[t]{2}{*}{ Carbon $\left(\mathrm{Mg} \mathrm{ha}^{-1}\right)$} & \multirow[t]{2}{*}{$\mathrm{CO}_{2}$ e $\left(\mathrm{Mg} \mathrm{C} \mathrm{ha}^{-1}\right)$} \\
\hline & Tree & Shrub & Herb & Total & & \\
\hline Dry Deciduous & $173.44 \pm 3.93$ & $1.57 \pm 0.17$ & $0.130 \pm 0.01$ & $175.14 \pm 4.53$ & $82.32 \pm 1.82$ & $301.83 \pm 6.66$ \\
\hline Moist Deciduous & $189.09 \pm 6.84$ & $1.28 \pm 6.84$ & $0.200 \pm 0.01$ & $190.57 \pm 6.83$ & $89.57 \pm 3.21$ & $328.42 \pm 10.50$ \\
\hline Evergreen & $232.59 \pm 12.90$ & $0.72 \pm 12.90$ & $0.092 \pm 0.01$ & $233.40 \pm 12.89$ & $109.70 \pm 6.06$ & $402.23 \pm 22.22$ \\
\hline
\end{tabular}

Table.4 Contribution of top ten tree species (based on IVI) to density $\left(\mathrm{ha}^{-1}\right)$, basal area $\left(\mathrm{m}_{2} \mathrm{ha}^{-1}\right)$, biomass $\left(\mathrm{Mg}^{-1}\right)$ and carbon stock $\left(\mathrm{Mg} \mathrm{ha}^{-1}\right)$ across the different forest types

\begin{tabular}{|c|c|c|c|c|c|c|c|c|c|c|c|c|}
\hline \multirow{2}{*}{ Species } & \multicolumn{4}{|c|}{ Dry Deciduous Forest } & \multicolumn{4}{|c|}{ Moist Deciduous Forest } & \multicolumn{4}{|c|}{ Evergreen Forest } \\
\hline & $\mathrm{D}$ & BA & $\mathrm{BIO}$ & $\mathrm{C}$ & $\mathrm{D}$ & $\mathrm{BA}$ & $\mathrm{BIO}$ & $\mathrm{C}$ & $\mathrm{D}$ & $\mathrm{BA}$ & $\mathrm{BIO}$ & $\mathrm{C}$ \\
\hline Anogeissus latifolia & 54.38 & 4.07 & 14.97 & 7.04 & 31.25 & 2.29 & 8.40 & 3.95 & & & & \\
\hline Artocarpus hirsutus & & & & & & & & & 8.75 & 1.77 & 10.97 & 5.16 \\
\hline Canarium strictum & & & & & & & & & 7.50 & 1.36 & 10.03 & 4.71 \\
\hline Cassia siamea & 13.13 & 0.79 & 2.81 & 1.32 & & & & & & & & \\
\hline Dalbergia latifolia & 26.88 & 2.36 & 12.48 & 5.87 & 20.00 & 1.95 & 10.59 & 4.98 & & & & \\
\hline Dimocarpus longan & & & & & & & & & 15.63 & 1.01 & 5.91 & 2.78 \\
\hline Elaeocarpus tuberculatus & & & & & & & & & 26.88 & 3.57 & 10.44 & 4.91 \\
\hline Gmelina arborea & 10.63 & 0.78 & 2.16 & 1.02 & & & & & & & & \\
\hline Grewia telieafolia & & & & & 12.50 & 2.00 & 8.35 & 3.93 & & & & \\
\hline Lagerstroemia lanceolate & 51.25 & 4.78 & 16.06 & 7.55 & 40.00 & 4.50 & 16.45 & 7.73 & 8.75 & 1.59 & 6.28 & 2.95 \\
\hline Lannea coromandalica & 8.75 & 1.18 & 4.28 & 2.01 & 19.38 & 1.41 & 8.01 & 3.77 & & & & \\
\hline Litsea floribunda & & & & & & & & & 13.75 & 0.72 & 2.96 & 1.39 \\
\hline Lophopetalum wightianum & & & & & & & & & 6.88 & 1.69 & 6.67 & 3.14 \\
\hline Mangifera indica & & & & & & & & & 8.75 & 0.91 & 4.54 & 2.13 \\
\hline Olea diocca & & & & & & & & & 15.63 & 0.90 & 5.79 & 2.72 \\
\hline Pterocarpus marsupium & 26.25 & 3.60 & 16.84 & 7.92 & 13.75 & 2.24 & 9.27 & 4.36 & & & & \\
\hline Syzygium cumini & & & & & & & & & 13.13 & 1.30 & 7.69 & 3.61 \\
\hline Tectona grandis & & & & & 20.63 & 1.75 & 7.37 & 3.46 & & & & \\
\hline Terminalia bellarica & 33.13 & 4.77 & 19.33 & 9.09 & 13.13 & 1.36 & 7.02 & 3.30 & & & & \\
\hline Terminalia paniculata & 10.63 & 1.01 & 4.44 & 2.09 & 20.00 & 1.94 & 8.96 & 4.21 & & & & \\
\hline Terminalia tomentosa & 61.25 & 6.32 & 41.31 & 19.42 & 86.25 & 8.61 & 56.64 & 26.62 & & & & \\
\hline
\end{tabular}

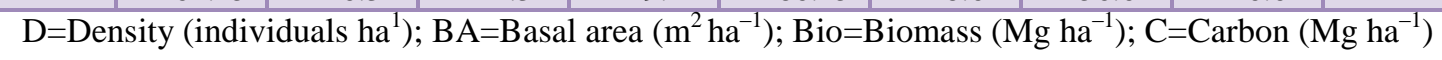


Fig.1 Map showing the study location in the Kodagu district

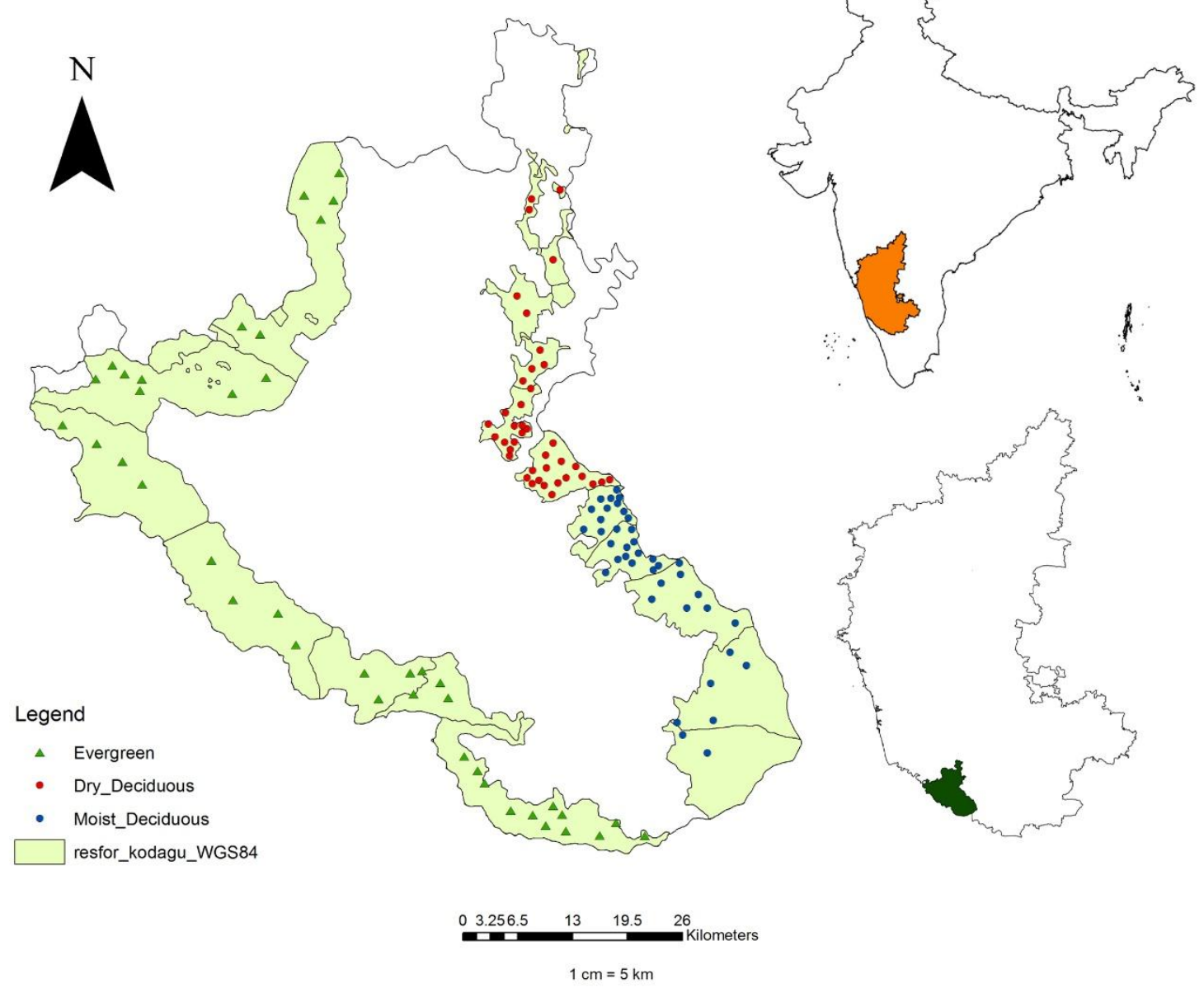

Fig.2 Nested sampling design followed during enumeration

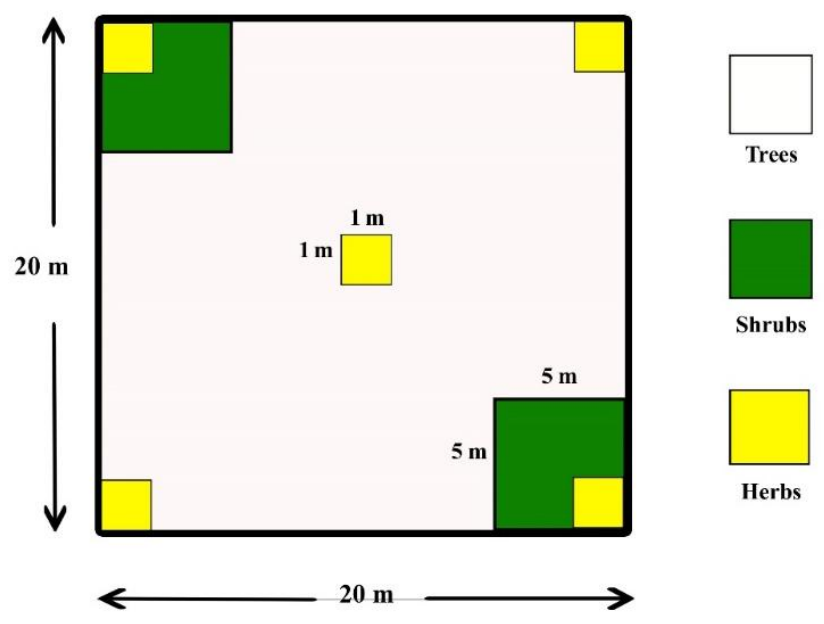


Fig.3 Girth class distribution of trees across different forest types

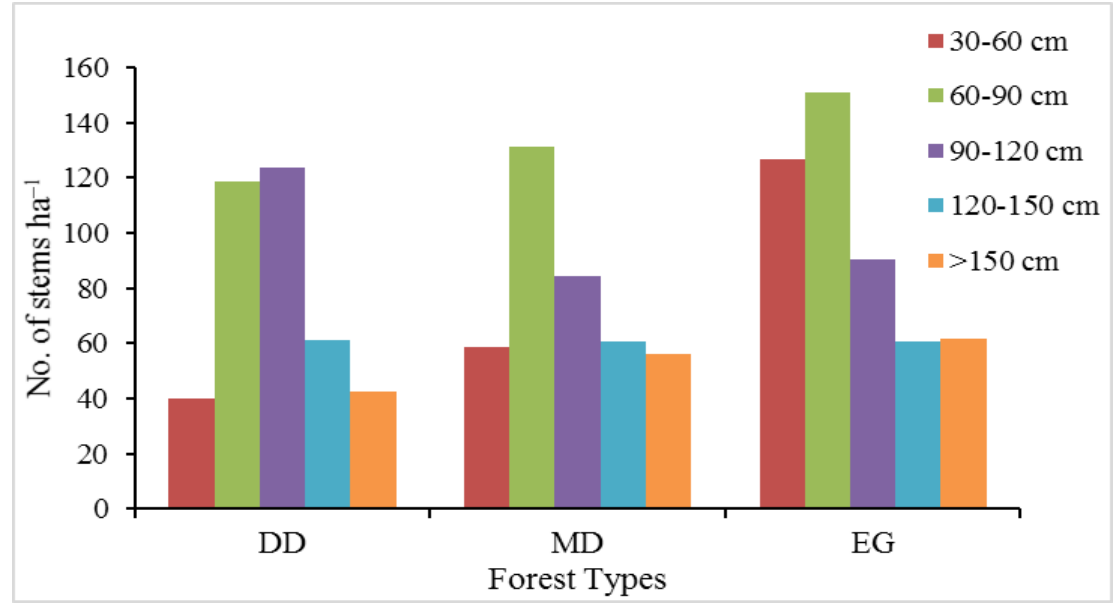

Fig.4 Contribution of biomass (Mg ha-1) by different girth class in dry deciduous forest type

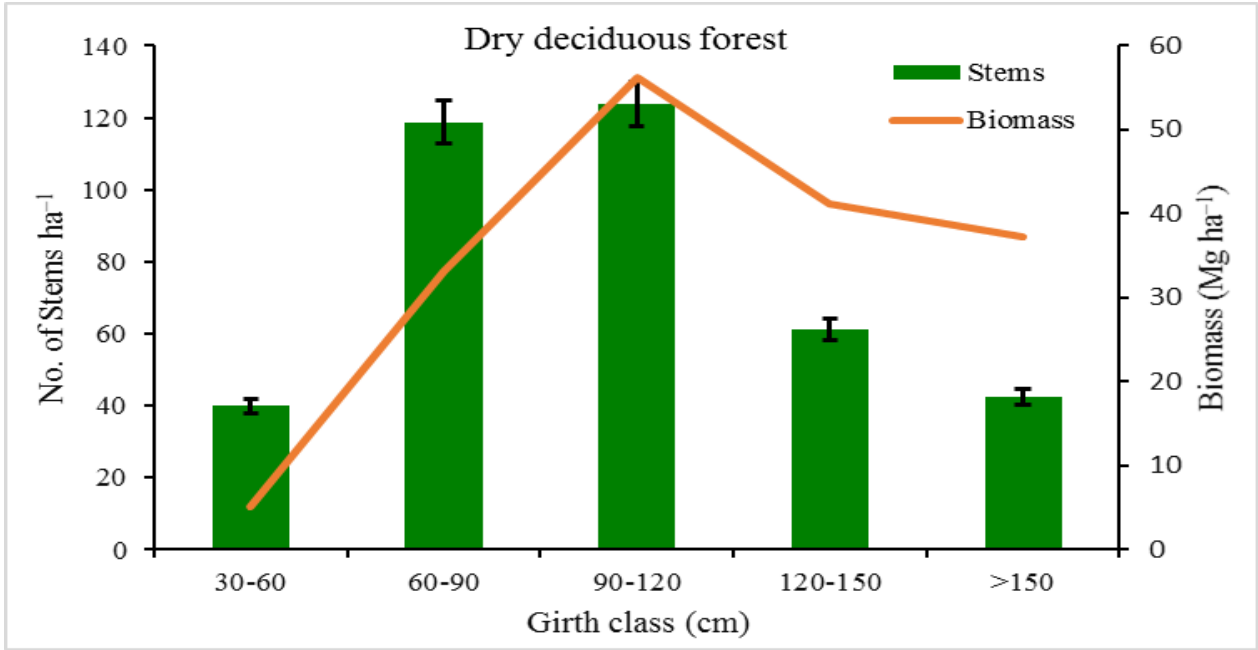

Fig.5 Contribution of biomass $\left(\mathrm{Mg} \mathrm{ha}^{-1}\right)$ by different girth class in moist deciduous forest type

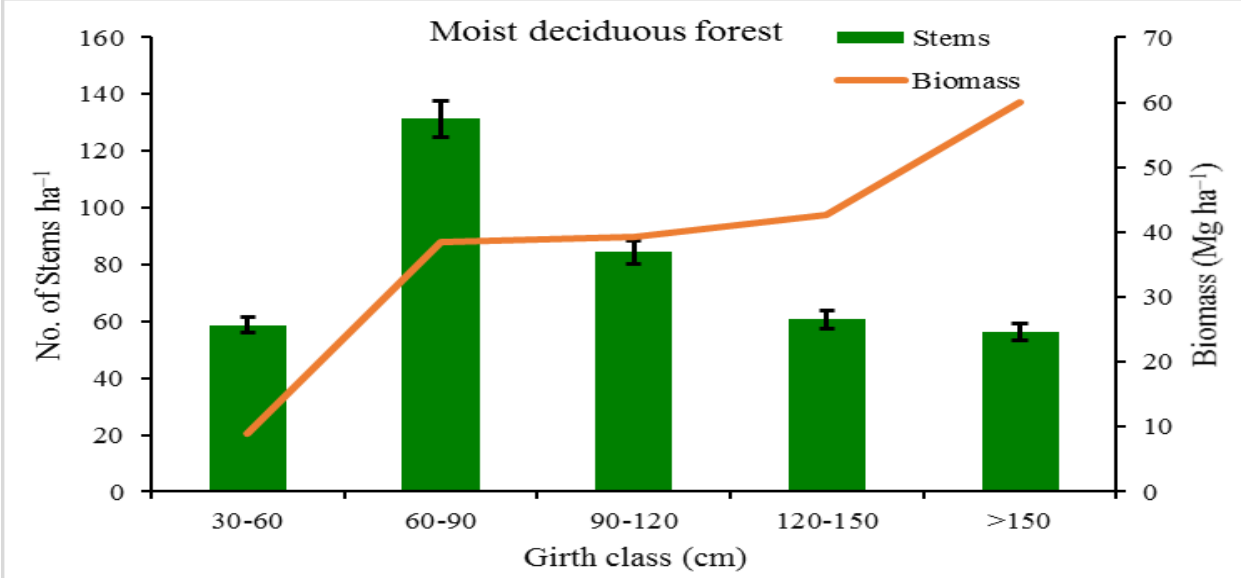


Fig.6 Contribution of biomass $\left(\mathrm{Mg} \mathrm{ha}^{-1}\right)$ by different girth class in evergreen forest type

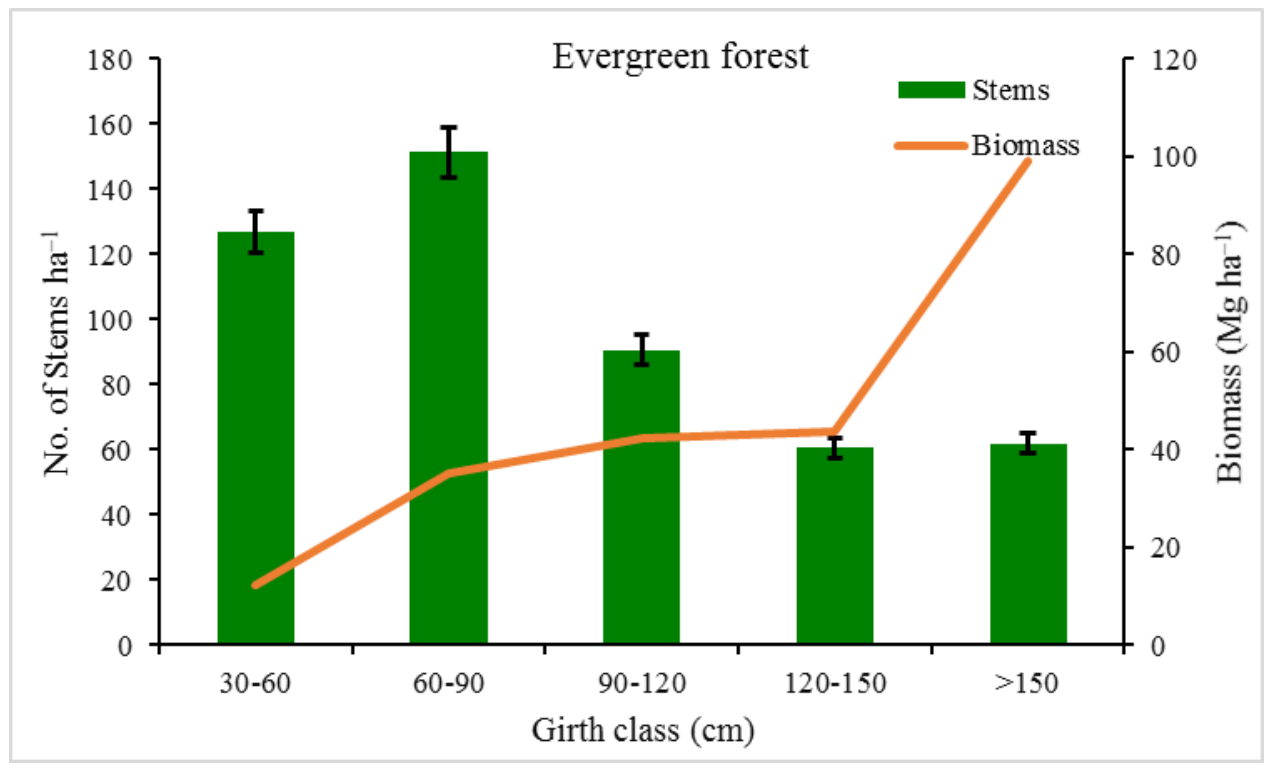

Biomass is not always reflected by the density. Data from our study was consistent with Devagiri et al., (2019), where few species will have less density, but contribute more towards biomass. Large trees play a vital role in influencing the AGB across various forests (Chaturvedi and Raghubanshi 2015). In the present study, more than $150 \mathrm{~cm}$ girth class had significantly contributed towards biomass in moist deciduous and evergreen forest types. The removal of trees in large girth class will have a serious impact on species diversity and composition of forests (Suratman, 2012).

Due to higher biomass recorded in evergreen forest type of Kodagu, they possess a carbon content of $109.7 \mathrm{Mg} \mathrm{ha}^{-1}$ followed by moist deciduous forests $\left(89.57 \mathrm{Mg} \mathrm{ha}^{-1}\right)$ and dry deciduous forests $\left(82.32 \mathrm{Mg} \mathrm{ha}{ }^{-1}\right)$. The amount of carbon stored in forests of Kodagu were lesser compared to undisturbed matured tropical rain forests of Malaysia (223 Mg ha $\left.{ }^{1}\right)$ reported by Brown and Lugu (1982). Ogawa et al., (1965) reported a carbon stock of $60-179 \mathrm{Mg} \mathrm{ha}^{-1}$ in different tropical forest types of Thailand, which were similar to AGBC value of dry deciduous forests in present study. Flint and Richard (1996) estimated carbon sequestration in Southeast Asian and reported $350 \mathrm{Mg} \mathrm{ha}^{-1}$ for the undisturbed mature tropical rain forests, which was very higher than the measured AGBC in all the three forest types of Kodagu.

In conclusion, across the different forest types, the species diversity, basal area, biomass and carbon varied between them. Highest diversity, biomass and carbon have been reported from evergreen forest type followed by moist deciduous and dry deciduous forests. Eloecarpus tuberculatus dominates the evergreen forests and Terminalia tomentosa dominated in both moist and dry deciduous forest types. $66.56 \%$ of the species existed in a moist deciduous forest is found in the dry deciduous forest with a very less in the occurrence of species in these forest types. Hence we can coin mixed deciduous forest instead of dry deciduous which is evident by density, diversity indices, basal area, species turnover between these forest types. Evergreen forest type contributes more for AGB and C stock among different forests. The larger trees in evergreen and moist deciduous forests 
contribute for more quantity of biomass and carbon. Hence more vigilant is required in these forest for preventing illicit logging which may degrade and deplete the forest.

\section{References}

Behera, S. K., Nayan, Sahu., Ashish K. Mishra, Surendra S. Bargali, Mukunda D Behere, Rakesh Tuli, 2017, Aboveground biomass and carbon stock assessment in Indian tropical deciduous forest and relationship with stand structural attributes. Ecological Engineering, 99: 513-524.

Brown, S and Lugo, A. E, 1982, The storage and production of organic matter in tropical forests and their role in the global carbon cycle. Biotropica, 14: 161-187.

Brown, S. L., Schroeder, P. and Kern, J.S., 1999, Spatial distribution of biomass in forest of the eastern USA. Forest Ecology and Management, 123: 81-90.

Carlson, K. M., Curran, L. M., Asner, G. P., Pittman, A. M., Trigg, S. N. and Adeney, J. M., 2013, Carbon emissions from forest conversion by Kalimantan oil palm plantations. Nat. Clim. Change, 3: 283287.

Chaturvedi, R. K. and Raghubanshi, A. S., 2015, Assessment of carbon density and accumulation in mono-and multi-specific stands in Teak and Sal forests of a tropical dry region in India. For. Ecol. Manag., 339: 11-21.

Chave, J., Andalo, C., Brown, S., Cairns, M. A., Chambers, J. Q., Eamus, D., Folster, H., Fromard, F., Higuchi, N., Kira, T., Lescure, J. P., Nelson, B. W., Ogawa, H., Puig, H., Riéra, B. and Yamakura, T., 2005, Tree allometry and improved estimation of carbon stocks and balance in tropical forests. Oecologia, 145, 8799.

Chave, J., Condit, R., Lao, S., Caspersen, J. P., Foster, R. B., Hubbell, S. O., 2003, Spatial and temporal variation of biomass, Journal of Ecology, 91: 240252.
Chazdon, R. L., Harvey, C. A., Komar, O., Griffith, D. M., Ferguson, B. G., Martínez-Ramos, M., Morales, H., Nigh, R., Soto-Pinto, L. and Van Breugel, M., 2009, Beyond reserves: a research agenda for conserving biodiversity in humanmodified tropical landscapes. Biotropica, 41: 142-153.

Curtis, J. T. And Mcintosh, R. P., 1950, The interrelations of certain analytic and synthetic phytosociological characters. Ecology, 31, 434-455.

Dadhwal, V. K., S. Singh and P. Patil. 2009. Assessment of phytomass carbon pools in forest ecosystems in India. Pp.41-47. NNRMS Bulletin. Indian Institute of Remote Sensing, Dehradun.

Devagiri, G. M., Khaple, A. K., Anithraj, H. B., Kushalappa, C. G., Krishnappa, A. K. and Mishra, S. B., 2019, Assessment of tree diversity and above-ground biomass in coffee agroforest dominated tropical landscape of India's Central Western Ghats. J. For. Res., Accepted (In Press).

Devagiri, G. M., Money, S., Sarnam, Singh, Dadhwal, V. K., Prasanth Patil, Khaple, A., Devakumar, S. A. and Hubballi, S., 2013, Assessment of above ground biomass and carbon pool in different vegetation types of south western part of Karnataka, India using spectral modelling. Trop. Ecol., 54(2): 149-165.

Flint, P. E. and Richards, J. F., 1996, Trends in carbon content of vegetation in South and Southeast Asia associated with change in land use: In: Dale, V. H. (ed.) Effects of Land-Use Change on Atmospheric $\mathrm{CO}_{2}$ Concentration, South and Southeast Asia as a Case Study. Springer-Verlag, Berlin, pp. 201-300.

FRI., 1996, Indian woods. Forest Research Institute, Dehra Dun, India, pp. 1-344.

FSI., 2006, Volume equations for forests of India, Nepal and Bhutan. Forest Survey of India, Ministry of Environment and Forests, Govt. of India, Dehra Dun, India, pp. 1-255.

Gibson, L., Lee, T. M., Koh, L. P., Brook, B. W., Gardner, T. A., Barlow, J., Peres, C. 
A., Bradshaw, C. J. A., Laurance, W. F., Lovejoy, T. E., Sodhi, N. S., 2011, Primary forests are irreplaceable for sustaining tropical biodiversity. Nature, 478: $378-381$

Kushalappa, C. G. and Kushalappa, K. A., 1998, Impact assessment of forest extraction in Kodagu. State Forest Department, Government of Karnataka, Bangalore, Technical Report, pp. 1-140.

IPCC, 2007. Climate Change 2007: Impacts, Adaptation and Vulnerability. Contribution of Working Group II to the Fourth Assessment Report of the Intergovernmental Panel on Climate Change, M. L. Parry, O. F. Canziani, J. P. Palutikof, P. J. Van Der Linden And C.E. Hanson, Eds., Cambridge University Press, Cambridge, UK, 976pp.

Magurran, A. E., 1988, Ecological Diversity and its Measurement. Princeton University Press, Princeton.

Murthy, I. K., Bhat, S., Sathynarayana, V., Patgar, S., Berrappa, M., Bhay, P. R., Bhat, D. M., Ravindranath, N. H., Khalid, M. A., Prashant, M., Iyer, S., Daniel, M. B. and Saxena, R., 2016, Vegetation structure and composition of tropical evergreen and deciduous forests in Uttara Kannada District, Western Ghats under different disturbance regimes. Tropical Ecology, 57: 77-88.

Ogawa,H., Yoda, K., Ogino, K., Kira, T., 1965, Comparative ecological studies on three main type of forest vegetation in Thailand II. Plant Biomass, Nat. Life South East Asia, 4: 49-80.
Pande, P. K. 2005. Biomass and productivity in some disturbed tropical dry deciduous teak forest of Satpura plateau, Madhya Pradesh. Tropical Ecology, 46: 229-239.

Pascal, J. P. and Pelissier, R., 1996. Structure and floristic composition of a tropical evergreen forest in South-West India. J. Trop. Ecol., 12: 191-214.

Phillips, H. R. P., Newbold, T., Purvis, A., 2017, Land use effects on local biodiversity in tropical forests vary between continents. Biodiversity Conservation, 26: 2251-2270.

Salunkhe, O., P. K. Khare, T. R. Sahu and Sarnam Singh., 2016, Estimation of tree biomass reserves in tropical deciduous forests of Central India by nondestructive approach. Tropical Ecology 57 (2): 153-161.

Suratman, M. N., 2012, Tree species diversity and forest stand structure of Pahang National Park, Malaysia In: Lameed, G. A. (Ed.), Biodiversity enrichment in a diverse in a diverse World. In Tech, New York.

Swamy, S. L., Dutt, C. B. S., Murthy, M. S. R., Alka, M. and Bargali, S. S., 2010, Floristic and dry matter dynamics of tropical wet evergreen forests of Western Ghats, India. Curr. Sci., 99: 353-364.

Turner, B. L., Lambin, E. F. and Reenberg, A, 2007, Land science special feature: the emergence of land change science for global environmental change and sustainability. Proc. Natl. Acad. Sci. USA. 104: 20672-20677.

\section{How to cite this article:}

Hareesh, T.S. and Nagarajaiah, C. 2019. Effect of Vegetation Structure and Species Composition on above Ground Biomass and Carbon in Forests of Central Western Ghats, India. Int.J.Curr.Microbiol.App.Sci. 8(04): 2762-2774. doi: https://doi.org/10.20546/ijcmas.2019.804.322 